\title{
Photoprotective Properties of Natural Pulvinic Acid Derivatives toward Ultraviolet-Induced Damages
}

\author{
Mehmet Varol (iD)*1
}

\author{
${ }^{1}$ Mugla Sitki Kocman University, Department of Molecular Biology and Genetics, Faculty of Science, TR48000, \\ Mugla, Turkey.
}

\begin{abstract}
Pulvinic acid derivatives are considered as worthy to be evaluated as skin protection factor toward ultraviolet-induced damages because of their colors and locations in lichens. Due to the lack of literature about photo-protective features of pulvinic acid derivatives, their cosmetic potentials for skin protection were evaluated in silico, for the first time. Computational chemistry, biology and pharmacology platforms such as Gaussian, GAMESS, PASS, PaDEL-DDPredictor and VEGA QSAR platforms were employed to determine the activities of pulvinic acid derivatives. Pulvinic acid derivatives were divided into three groups as the most promising, promising and unpromising compounds according to the calculated $p$-values. Although leprapinic acid, demethylleprapinic acid, pinastric acid, leprapinic acid methyl ether, 4-hydroxyvulpinic acid and vulpinic acid were determined as the most promising compounds, epanorin and rhizocarpic acid were identified as promising compounds. The proposed model seems to be reliable because the calculated $p$-value for vulpinic acid was found to be compatible with previously obtained experimental results. The pulvinic acid derivatives that were identified as the most promising ones should be therefore further studied by in vitro and in vivo multiple experiments.
\end{abstract}

\section{ARTICLE HISTORY}

Received: 05 September 2018

Revised: 09 November 2018

Accepted: 20 November 2018

\section{KEYWORDS}

Lichen,

Ultraviolet,

Photoprotective,

Pulvinic Acid,

$p$-value

\section{INTRODUCTION}

Lichens are known as ecologically obligate associations between photobionts that transfer and release necessary carbohydrates such as ribitols, erythritols or sorbitols, and mycobionts that provide a humid and safe environment $[1,2]$. Lichens have adapted to live in almost every habitat on the planet including the extreme ones such as high mountains, dry deserts or the Polar Regions, where the depletion of the ozone layer is dramatically higher [3]. Moreover, lichens are considered as the pioneer organisms on rock surfaces, dead woods, living barks of trees, animal bones, and even on the man-made surfaces such as rusty metals or the surfaces of the medieval buildings where are also dramatically exposed to ultraviolet rays [4,1]. Lichens have achieved to live under the intense ultraviolet rays by using a series of adaptation mechanisms

CONTACT: Mehmet Varol $\bigotimes$ mehmetvarol@mu.edu.tr mehmetv@hotmail.it $\equiv$ Mugla Sitki Kocman University, Department of Molecular Biology and Genetics, Faculty of Science, TR48000, Mugla, Turkey. Phone: 0090-252-211-31-32, Fax: +90-252-223-92-80 
such as the membrane and macromolecule repair systems, antioxidant defense, thermal dissipation, light scattering and radiation screening [5]. The adaptation of lichens to the extreme conditions seems to be also connected to their secondary metabolites (ca. 1000) that are mainly synthesized by the fungal partner of lichen association and produced by depending on the environmental stress factors such as temperature fluctuations, drought, excess light or ultraviolet rays [6-8]. Pulvinic acid derivatives are considered as potential photoprotective substances due to their chemical structure, having an oxolane-carbonyl chromophore unit, present ultraviolet (UV) profiles characterized by two absorption bands with a high absorption coefficient, and their locality in the lichen thalli where are the most exposed parts of lichens to ultraviolet rays [5]. Moreover, it is known that biosynthesis rates of pulvinic acid derivatives, e.g., calycin or rhizocarpic acid, are increased with the increasing levels of ultraviolet radiation $[9,10]$. Although the similarity is a fundamental concept that has been used for more than two centuries in the sciences, perspective of structure-activity relationships in medicinal chemistry has been started to emerge as a central paradigm and distinct discipline in the late 1990s [1113]. According to the perspective of structure-activity relationships that can be defined as the application of mathematical and computer models to predict biological activity depending on its chemical structure, similar molecules should also display similar biological activity [13]. The perspective of structure-activity relationships is a rapidly developing and widely accepted discipline because it has provided research and development (R\&D) budget- and labor-saving feature for the screening of the vast variety of compounds [14]. In this research, we would like to investigate the photoprotective potential of pulvinic acid derivatives by using a combination of computational models because there is an increasing interest of scientist and great need to discover new natural photoprotective substances from certain organisms, including lichens, and the photoprotective capacity of pulvinic acid derivatives is considered as worthy [15-17,5].

\section{MATERIAL and METHODS}

Chemical structures of pulvinic acid derivatives that are composed by calycin, epanorin, pinastric acid, rhizocarpic acid, leprapinic acid, leprapinic acid methyl ether, demethylepropinic acid, pulvinic acid, pulvinamide, pulvinic acid lactone, 2-hydroxypulvinic acid lactone, vulpinic acid and 4-hydroxyvulpinic acid were quoted from the book written by Huneck and Yoshimura (1996) and drawn by using Chem3D 17.0 [18]. Vitamin E ( $\alpha$-tocopherol) was used as positive control and the chemical structure was obtained from the PubChem open chemistry database [19,3]. To identify the optimized geometric and electronic structure of pulvinic acid derivatives, Gaussian 03 software with Hartree-Fock (HF) theory at the B3LYP/3-21G level was employed by ab-initio quantum mechanical calculations based on Density Functional Theory (DFT). Although the experimental ultraviolet/visible spectrum species in methanol were quoted from the book published by Huneck and Yoshimura (1996), GAMESS software with $\mathrm{HF}$ theory at the $3-21 \mathrm{G}$ basis set was performed to determine the predicted ultraviolet/visible spectrum species by using the geometrically optimized 3D chemical structures of compounds. Then, PASS (Prediction of Activity Spectra for Substances) online provided by Way2Drug Team was performed to determine photosensitizer, cytotoxic, cytoprotectant, free radical scavenger, antioxidant, irradiation, skin irritation, ocular toxicity, antipruritic and anti-allergic, antibacterial and anti-inflammatory potentials of pulvinic acid derivatives [20]. To determine reactive metabolites forms adduct, skin irritation, serious eye damage, serious eye irritation and eye/skin corrosion potentials of compounds, PaDELDDPredictor software were employed [21]. Additionally, skin sensitization model (CAESAR) 2.1.6 in VEGA QSAR platform was used to identify skin sensitization potentials of pulvinic acid derivatives [22]. After the first $p$-values $(\boldsymbol{x})$ of the compounds were determined for the activities that were mentioned above, the activities were divided into two groups as positive factors and negative factors to be a photoprotective compound and a relative weight as 
percentage ( $w$ ) was given for each activity by using previous experimental experience $[23,3]$. Then, a positive weighted average value $\left(W_{a v g_{I(+)}}\right)$ for the positive factors and a negative weighted average value $\left(W_{\text {avg }}{ }_{I(-)}\right)$ for the negative factors were calculated by using the formula given below. Consequently, a final $p$-value was calculated by addition of the previously obtained two values.

$$
\begin{aligned}
& W_{\text {avg }_{I}}=w_{1} x_{1}+w_{2} x_{2}+\cdots+w_{n} x_{n} \\
& p=W_{\text {avg }}+W_{\text {I(+) }}+W_{\text {avg }}(-)
\end{aligned}
$$

\section{RESULTS}

The two-dimensional (2D) chemical structures and three-dimensional (3D) conformations of pulvinic acid derivatives and $\alpha$-tocopherol were given in Table 1 . To predict ultraviolet/visible spectrum species of the compounds, GAMESS software was employed and the obtained spectra were given in Table 1. As can be seen in Fig. 1 and Fig. 2, the predicted UV/Vis values were generally compatible with the experimentally obtained ultraviolet/visible spectrum species of the compounds in methanol. Although the absorption spectra of pulvinic acid derivatives are generally observed in ultraviolet $\mathrm{A}$ and ultraviolet $\mathrm{C}$, the experimental spectra in methanol $(\mathrm{MeOH})$ have displayed that vulpinic acid and pinastric acid could absorb the light within the ultraviolet B wavelength (Fig. 1 and Fig. 2).

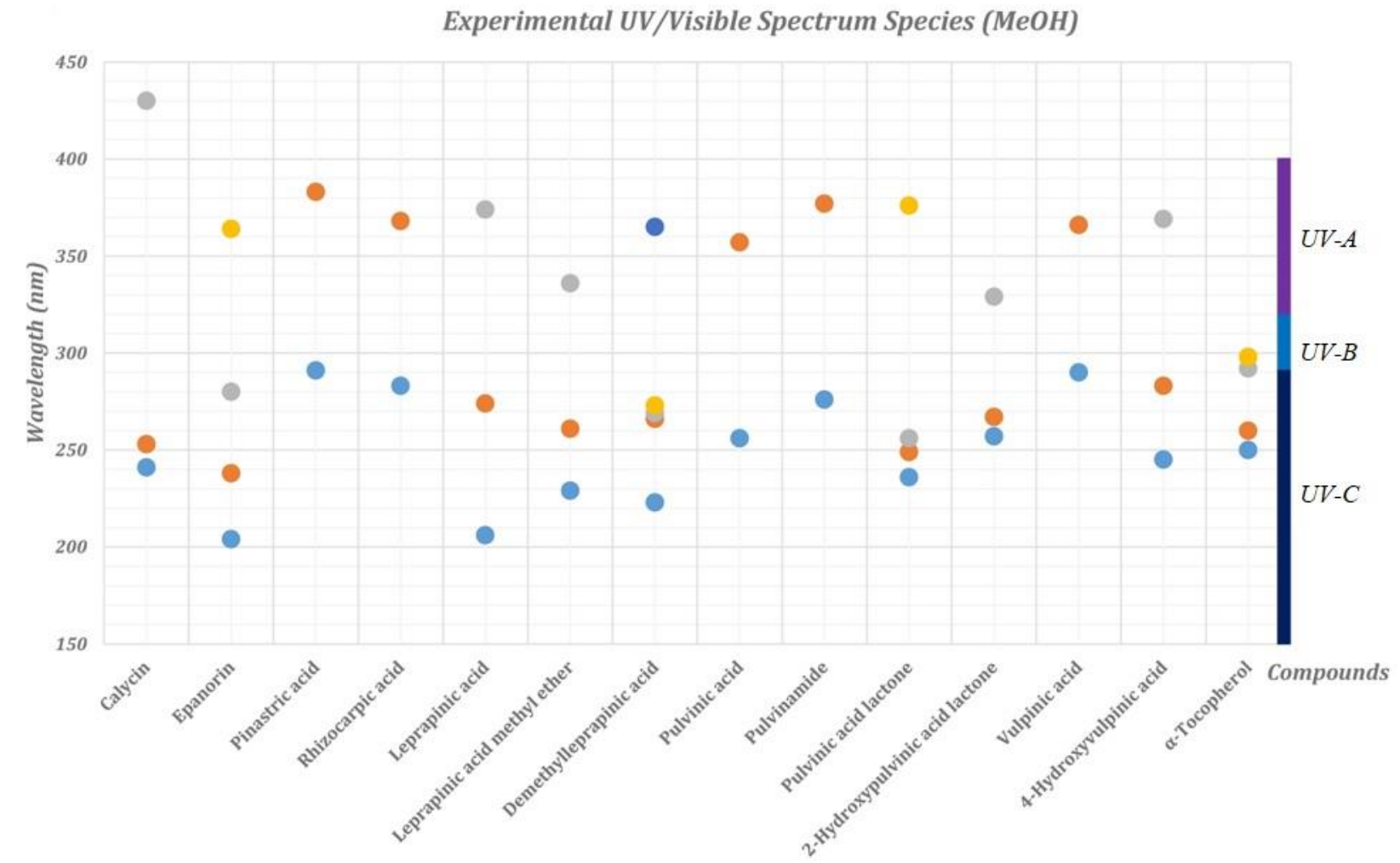

Fig. 1. Experimentally obtained UV/Visible spectrum species of the pulvinic acid derivatives and $\alpha-$ tocopherol in methanol. 
UV/Visible Spectrum Species (GAMESS Interface)

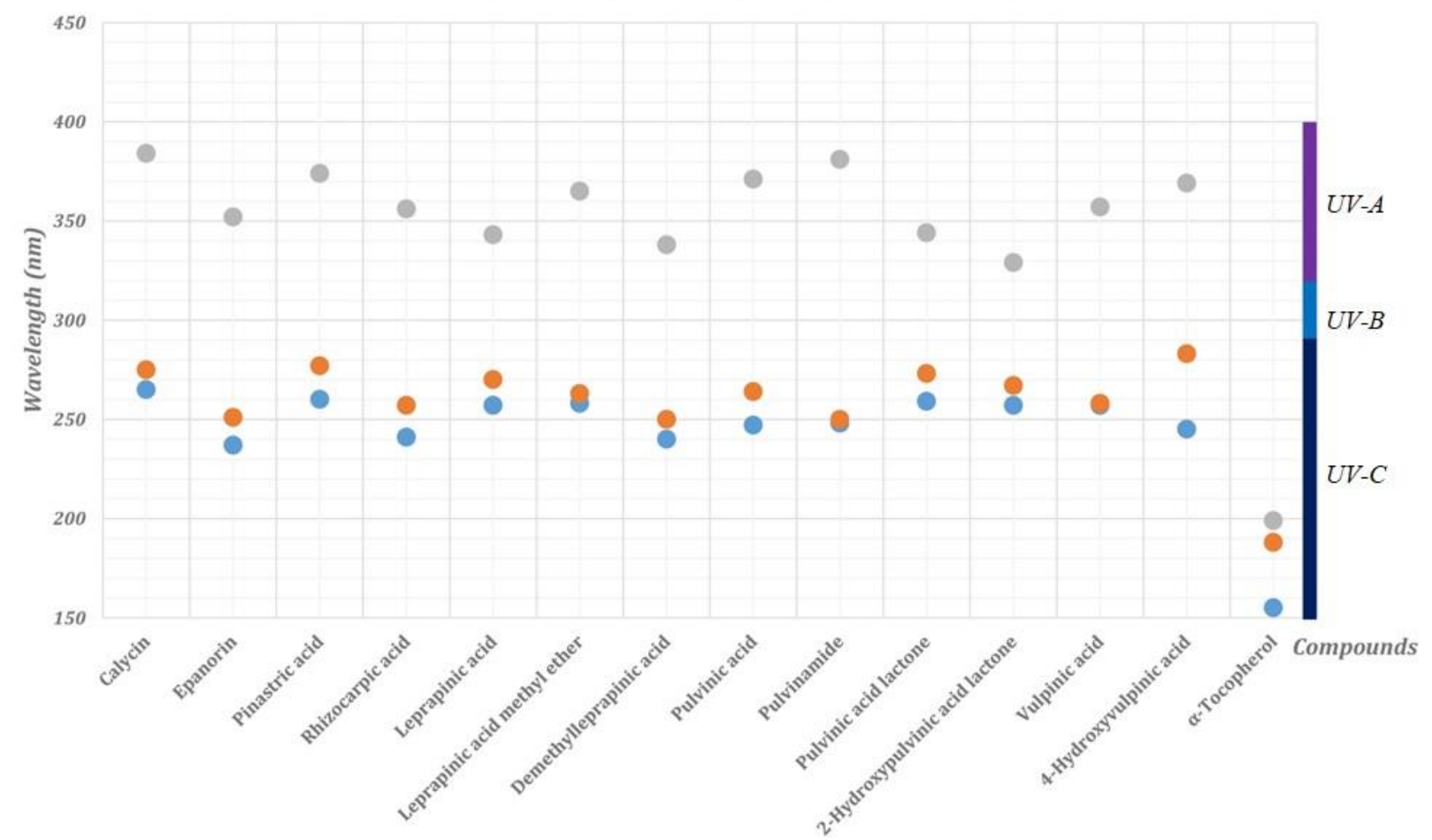

Fig. 2. Computationally obtained UV/Visible spectrum species of the pulvinic acid derivatives and $\alpha$ tocopherol by GAMESS interface in Chem3D 17.0 software.

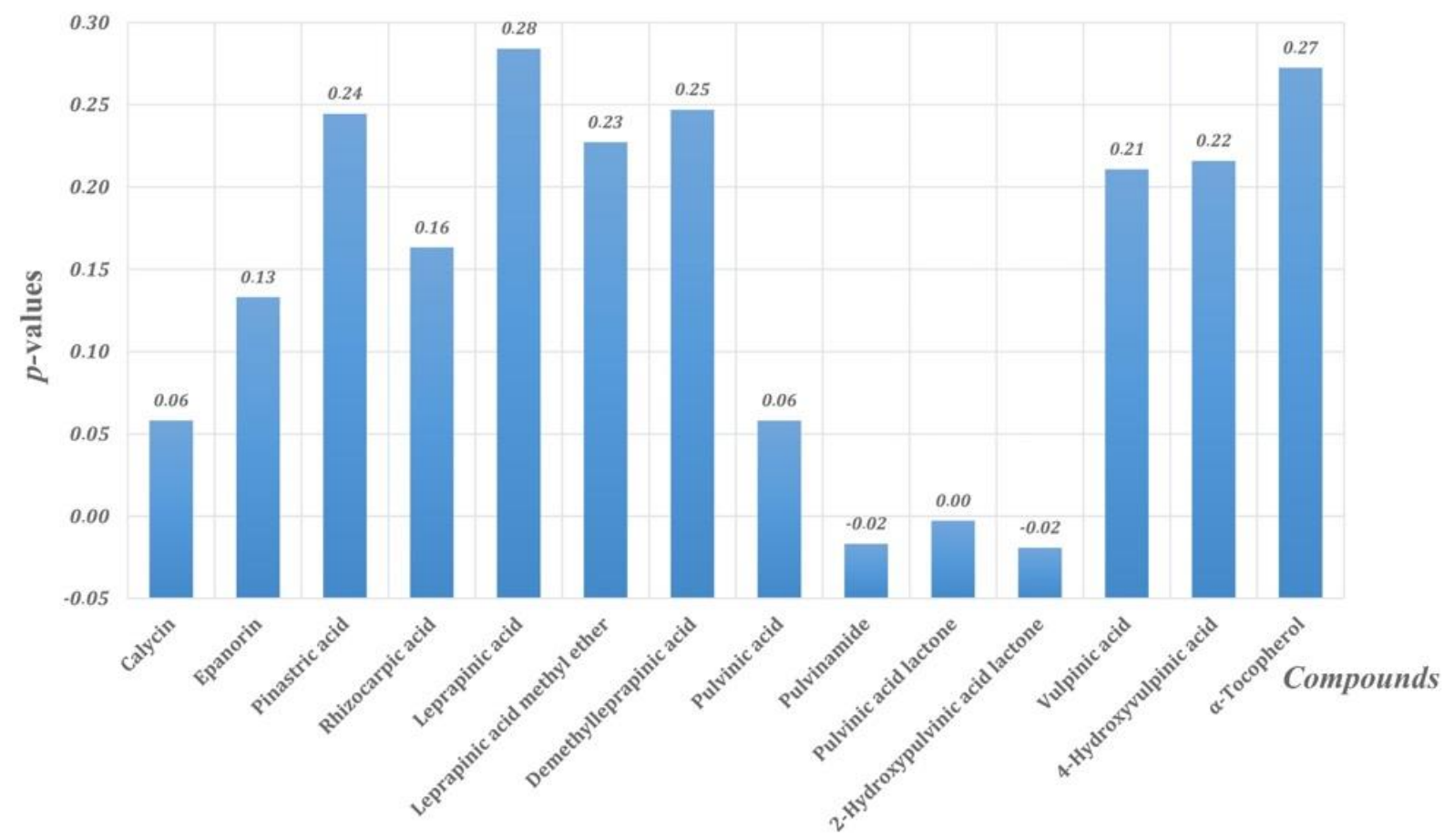

Fig. 3. The comparison of photoprotective capabilities of pulvinic acid derivative toward ultraviolet light-induced skin damages according to the statistically obtained $p$-values.

After the UV/Vis spectrum species were evaluated, some protective and harmful activities that are related to skin protection towards ultraviolet rays were computationally evaluated by using PASS, PaDEL-DDPredictor and VEGA QSAR platforms as can be seen in Table 2. After 
the data were obtained from in silico platforms, a $p$-value was calculated for each compound and $p$-values were framed as a graph for the comparison of photoprotective capabilities of pulvinic acid derivative toward ultraviolet light-induced skin damages (Fig. 3).

\section{DISCUSSION and CONCLUSION}

Nature has been of great importance as a generous source of nutrition, poison and remedy throughout the history of humankind, and the ancient relationship between humankind and nature affects the people's preferences in favor of natural products for drugs, cosmetics and care products [24]. Pharmaceutical industry and cosmetic companies have therefore given more importance and allocated a significant amount of $R \& D$ budget to discover active natural products or functional ingredients $[25,26]$.

Although the rational and best way to search for potentially active ingredients of cosmetics, drugs and care products seems to be the testing of substances obtained from the natural sources such as plants, animals or fungus, there are some limitations such as costly and/or time-consuming detection processes of the cosmetically and pharmacologically active compounds that are located within these highly structured-organisms due to the complex compound contents of them [27]. Nonetheless, lichens that are defined as a complex symbiotic organisms composed by a photobiont and a mycobiont, which have a tight metabolic relationship with each other, emerge to provide the researchers many advantages by their simple but very active secondary metabolite contents that can be easily isolated by the basic isolation method such as thin layer chromatography [28-30]. On the other hand, it should be noted that the R\&D departments of companies and governments, and researchers would like to prefer R\&D budget- and labor-saving alternatives such as in silico biological activity prediction platforms depending on the mathematical relationships of chemical structures and biological activities $[13,14]$. In the present study, the photoprotective and destructive activities of lichenoriginated pulvinic acid derivatives were investigated by using different in silico platforms and the authenticity of the obtained data was evaluated, to the best of our knowledge for the first time, by comparing the experimentally obtained data in the literature. Due to the skin protection capability against ultraviolet rays, $\alpha$-tocopherol was applied as positive control in silico models $[19,3,31]$. The calculated $p$-values and obtained data from the in silico models showed that pulvinic acid derivatives could be divided into three main groups that composed by unpromising, promising and significantly promising as the photoprotective substances toward ultraviolet-induced skin damage (Table 2 and Fig. 3). 
Table 1. The two- and three- dimensional chemical structures and UV/Vis spectrum data of pulvinic acid derivatives and $\alpha$-tocopherol.

*** indicates that there is no information in literature.

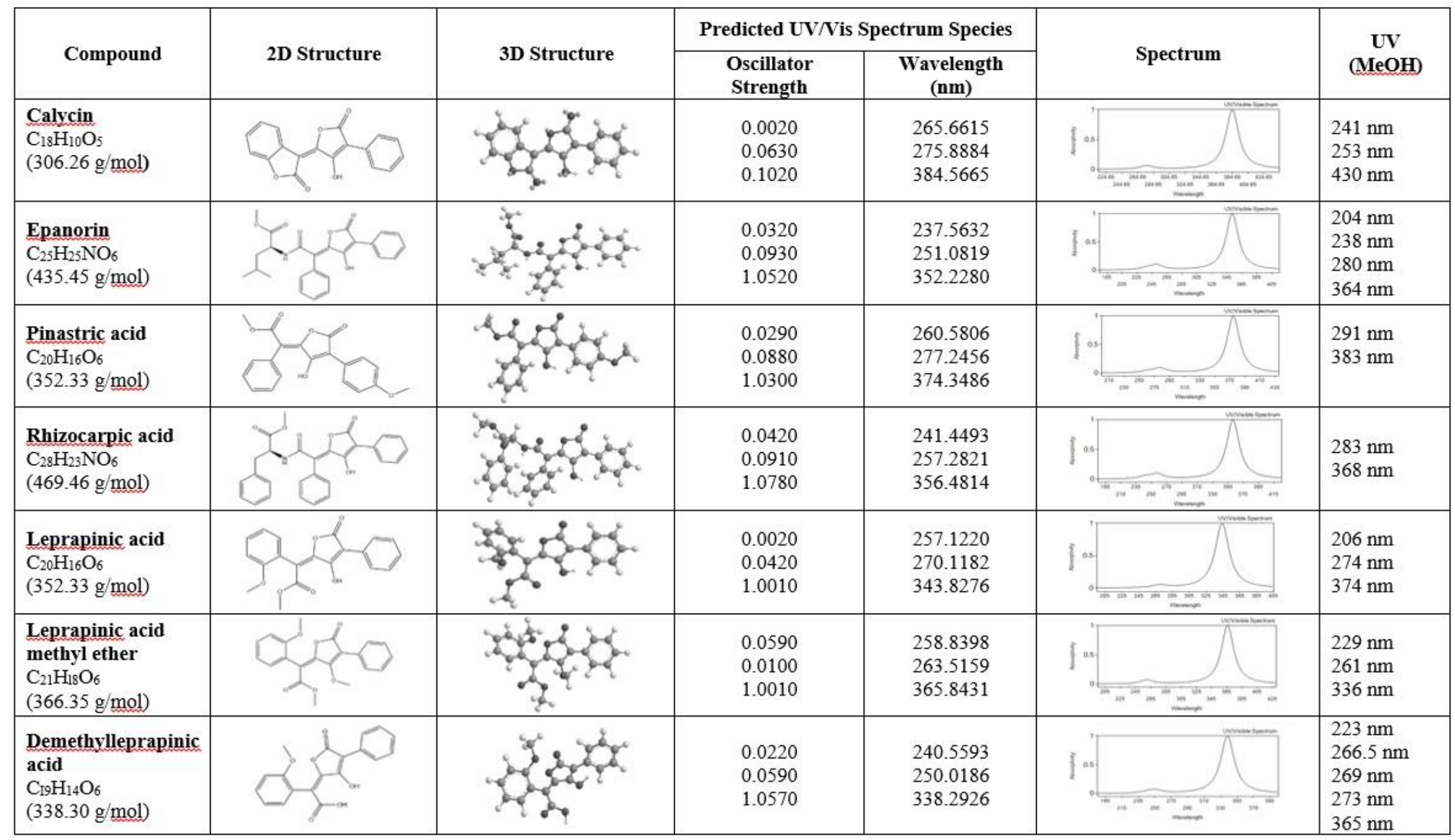


Table 1. (Continued)

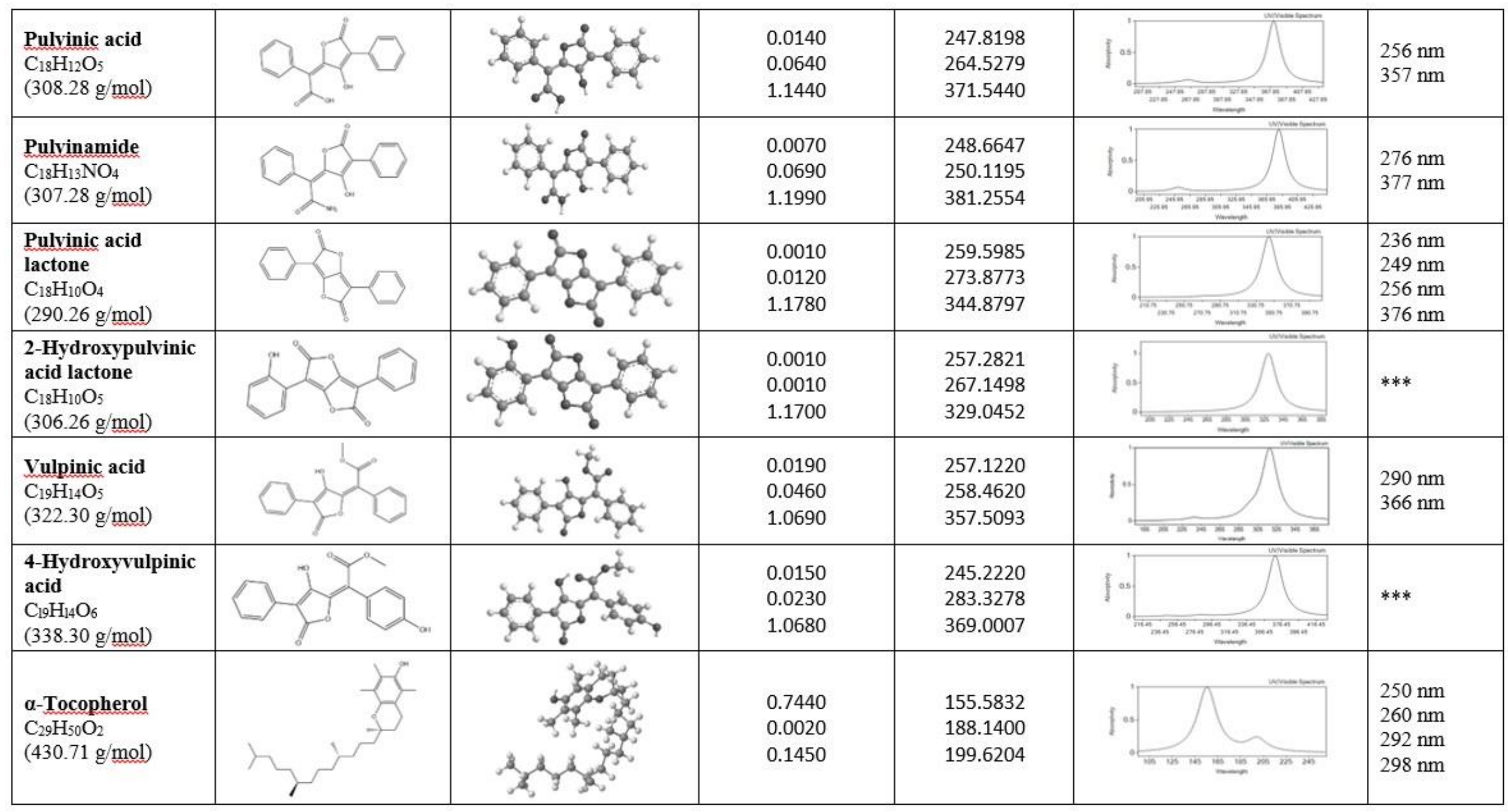


Table 2. The computationally evaluated activities on PASS, PaDEL-DDPredictor and VEGA QSAR platforms, the given relative weights as percentages ( $w$ ) and calculated $p$-values (weighted averages).

\begin{tabular}{|c|c|c|c|c|c|c|c|c|c|}
\hline Compound & $\begin{array}{c}\text { Photosensitizer } \\
\text { (PASS })\end{array}$ & $\begin{array}{l}\text { Cytotoxic } \\
\text { (PASS) }\end{array}$ & $\begin{array}{l}\text { Cytoprotectant } \\
\quad(\text { PASS })\end{array}$ & \begin{tabular}{|c|} 
Reactive Metabolites \\
forms adduct \\
(PADEL)
\end{tabular} & $\begin{array}{c}\text { Free radical } \\
\text { scavenger } \\
(\text { PASS }) \\
\end{array}$ & $\begin{array}{l}\text { Antioxidant } \\
\quad(\text { PASS })\end{array}$ & $\begin{array}{l}\text { Irritation } \\
(\text { PASS })\end{array}$ & $\begin{array}{l}\text { Skin irritation } \\
\quad(\text { PASS })\end{array}$ & $\begin{array}{l}\text { Skin Irritation } \\
\quad(\text { PADEL })\end{array}$ \\
\hline Calycin & 0,523 & 0,240 & 0,379 & Positive & 0,438 & 0,307 & 0,241 & 0,192 & Negative \\
\hline Epanorin & 0,307 & 0,296 & 0,284 & Negative & 0,275 & 0,221 & 0,285 & 0,186 & Negative \\
\hline Pinastric acid & 0,351 & 0,223 & 0,497 & Negative & 0,407 & 0,288 & - & 0,095 & Negative \\
\hline Rhizocarpic acid & 0,351 & 0,221 & 0,338 & Negative & 0,287 & 0,234 & 0,199 & 0,186 & Negative \\
\hline Leprapinic acid & 0,351 & 0,169 & 0,537 & Negative & 0,386 & 0,276 & - & 0,170 & Negative \\
\hline $\begin{array}{l}\text { Leprapinic acid } \\
\text { methyl ether }\end{array}$ & 0,345 & - & 0,476 & Negative & 0,235 & 0,131 & - & 0,158 & Negative \\
\hline $\begin{array}{c}\text { Demethylleprapinic } \\
\text { acid }\end{array}$ & 0,359 & 0,212 & 0,585 & Negative & 0,467 & 0,298 & 0,187 & 0,178 & Negative \\
\hline Pulvinic acid & 0,378 & 0,273 & 0,554 & Positive & 0,403 & 0,339 & 0,250 & 0,288 & Negative \\
\hline Pulvinamide & 0,344 & 0,258 & 0,505 & Positive & 0,339 & 0,288 & 0,207 & 0,166 & Negative \\
\hline Pulvinic acid lactone & 0,468 & 0,240 & 0,504 & Positive & 0,315 & 0,220 & 0,307 & 0,290 & Negative \\
\hline $\begin{array}{c}\text { 2-Hydroxypulvinic } \\
\text { acid lactone }\end{array}$ & 0,444 & 0,345 & 0,463 & Positive & 0,455 & 0,325 & 0,312 & 0,236 & Negative \\
\hline Vulpinic acid & 0,381 & 0,229 & 0,491 & Negative & 0,347 & 0,295 & 0,177 & 0,105 & Negative \\
\hline $\begin{array}{c}\text { 4-Hydroxyvulpinic } \\
\text { acid }\end{array}$ & 0,341 & 0,243 & 0,502 & Negative & 0,403 & 0,315 & 0,184 & 0,108 & Negative \\
\hline$\alpha$-Tocopherol & 0,252 & 0,490 & - & Negative & 0,783 & 0,968 & 0,223 & 0,178 & Positive \\
\hline Relative weight (\%) & +15 & -15 & +15 & -15 & +20 & +20 & -15 & -15 & -5 \\
\hline
\end{tabular}


Table 2. (Continued)

\begin{tabular}{|c|c|c|c|c|c|c|c|c|c|}
\hline Compound & $\begin{array}{c}\text { Skin } \\
\text { Sensitization } \\
(\text { VEGA TOX) }\end{array}$ & $\begin{array}{c}\text { Ocular toxicity } \\
\quad(P A S S)\end{array}$ & $\begin{array}{c}\text { Serious Eye } \\
\text { Damage } \\
(\text { PADEL })\end{array}$ & $\begin{array}{c}\text { Serious Eye } \\
\text { Irritation } \\
(\text { PADEL })\end{array}$ & $\begin{array}{c}\text { Eye/Skin } \\
\text { Corrosion } \\
(\text { PADEL })\end{array}$ & $\begin{array}{c}\text { Antipruritic, } \\
\text { anti-allergic } \\
(P A S S)\end{array}$ & $\begin{array}{c}\text { Antibacterial } \\
(\text { PASS })\end{array}$ & $\begin{array}{c}\text { Anti- } \\
\text { inflammatory } \\
(P A S S)\end{array}$ & $\begin{array}{c}\text { Weighted } \\
\text { Average }\end{array}$ \\
\hline Calycin & $\begin{array}{c}\text { Sensitizer } \\
\text { Reliability * }\end{array}$ & 0,371 & Negative & Negative & Negative & 0,471 & 0,384 & 0,413 & 0,058125 \\
\hline Epanorin & $\begin{array}{c}\text { NON-Sensitizer } \\
\text { Reliability * }\end{array}$ & 0,408 & Negative & Negative & Negative & 0,390 & 0,174 & 0,666 & 0,133100 \\
\hline Pinastric acid & $\begin{array}{c}\text { Sensitizer } \\
\text { Reliability * }\end{array}$ & 0,331 & Negative & Negative & Negative & 0,293 & 0,164 & 0,926 & 0,244550 \\
\hline Rhizocarpic acid & $\begin{array}{c}\text { NON-Sensitizer } \\
\text { Reliability * }\end{array}$ & 0,273 & Negative & Negative & Negative & 0,244 & - & 0,680 & 0,163300 \\
\hline Leprapinic acid & $\begin{array}{c}\text { Sensitizer } \\
\text { Reliability * }\end{array}$ & - & Negative & Negative & Negative & 0,253 & 0,164 & 0,921 & 0,284075 \\
\hline $\begin{array}{l}\text { Leprapinic acid } \\
\text { methyl ether }\end{array}$ & $\begin{array}{c}\text { Sensitizer } \\
\text { Reliability * }\end{array}$ & - & Negative & Negative & Negative & 0,232 & - & 0,931 & 0,227275 \\
\hline $\begin{array}{c}\text { Demethylleprapinic } \\
\text { acid }\end{array}$ & $\begin{array}{c}\text { Sensitizer } \\
\text { Reliability * }\end{array}$ & 0,285 & Negative & Negative & Negative & 0,310 & 0,229 & 0,906 & 0,246925 \\
\hline Pulvinic acid & $\begin{array}{c}\text { Sensitizer } \\
\text { Reliability } *\end{array}$ & 0,385 & Negative & Negative & Negative & 0,391 & 0,270 & 0,938 & 0,058050 \\
\hline Pulvinamide & $\begin{array}{c}\text { Sensitizer } \\
\text { Reliability * }\end{array}$ & 0,391 & Positive & Negative & Negative & 0,306 & 0,330 & 0,841 & $-0,016825$ \\
\hline Pulvinic acid lactone & $\begin{array}{c}\text { Sensitizer } \\
\text { Reliability * }\end{array}$ & 0,393 & Negative & Negative & Negative & 0,463 & 0,317 & 0,476 & $-0,002775$ \\
\hline $\begin{array}{c}\begin{array}{c}\text { 2-Hydroxypulvinic } \\
\text { acid lactone }\end{array} \\
\end{array}$ & $\begin{array}{c}\text { Sensitizer } \\
\text { Reliability * }\end{array}$ & 0,415 & Positive & Negative & Negative & 0,462 & 0,375 & 0,500 & $-0,019225$ \\
\hline Vulpinic acid & $\begin{array}{c}\text { Sensitizer } \\
\text { Reliability * }\end{array}$ & 0,350 & Negative & Negative & Negative & 0,301 & 0,199 & 0,942 & 0,210775 \\
\hline \begin{tabular}{|c|} 
4-Hydroxyvulpinic \\
acid
\end{tabular} & $\begin{array}{c}\text { Sensitizer } \\
\text { Reliability * }\end{array}$ & 0,344 & Negative & Negative & Negative & 0,290 & 0,189 & 0,933 & 0,215850 \\
\hline$\alpha$-Tocopherol & $\begin{array}{c}\text { Sensitizer } \\
\text { Reliability } *\end{array}$ & 0,284 & Negative & Negative & Negative & 0,217 & 0,213 & 0,830 & 0,272525 \\
\hline Relative weight (\%) & -5 & -15 & -5 & -5 & -5 & +15 & $+7,5$ & $+7,5$ & \\
\hline
\end{tabular}


Although pulvinic acid derivatives display ultraviolet profiles qualified by two absorption bands with a high absorption coefficient, some pulvinic acid derivatives such as calycin, pulvinic acid, pulvinamide, pulvinic acid lactone and 2-hydroxypulvinic acid lactone were identified as unpromising photoprotective substances due to their low $p$-values that were statistically obtained by the negative and positive factors (Table 2 and Fig. 3). Calycin, pulvinic acid lactone and 2-hydroxypulvinic acid lactone, for example, seem to be the most active photosensitizer substance by the predicted values in PASS platform but they have also serious negative effects such as the adduct formation by reactive metabolites, skin sensitization, irradiation, etc., as can be seen in Table 2. Thence, the photoprotective and other beneficial effects of these substances are suppressed by the negative activities. In the literature, there are some studies about rhizocarpic acid that is determined in the present study as promising photoprotective substance depending on the calculated $p$-value (Table 2) [32,9]. Compatible with our predicted results, Rubio and co-workers (2002) have suggested that the accumulation of rhizocarpic acid in lichens is increased depending on UV-B radiation levels [9]. On the other hand, pinastric acid, leprapinic acid, demethylleprapinic acid, leprapinic acid methyl ether, 4hydroxyvulpinic acid and vulpinic acid were determined as the most promising photoprotective compounds toward ultraviolet-induced skin damage (Table 2). Vulpinic acid seems to be most studied one in these significantly promising compounds and previously obtained results showed that vulpinic acid is a good candidate as a photoprotective compounds against ultravioletinduced skin damage by having no significant toxic effects and harmlessly elimination capability of the absorbed energy from the ultraviolet rays [3,5]. Similarly, the studies about pinastric acid have showed that pinastric acid have an antioxidant, photoprotective and neuroprotective acitivities in a correlation with our in silico data $[33,34]$. However, there is no reference about the protective or harmful features of other pulvinic acid derivatives, which have been identified as the significantly promising photoprotective compounds in our in silico data. Consequently, this paper reveals that the mathematical and computer models that have been generated by the perspective of structure-activity relationships provide significantly realistic results though these in silico platforms need to be improved by supporting more data about structure-activity relationships. We therefore think that researchers the computational chemistry, biology and pharmacology platforms such as Gaussian, GAMESS, PASS, PaDELDDPredictor and VEGA QSAR should be employed more to improve the scientific quality and discussion perspective of the produced research papers and projects, and to decrease the necessary R\&D budget and workload.

\section{Conflict of Interest}

The authors declare that there is no conflict of interest regarding the publication of this paper.

\section{ORCID}

Mehmet Varol (D) https://orcid.org/000-0003-2565-453X

\section{REFERENCES}

[1] Stocker-Wörgötter, E. (2015). Biochemical Diversity and Ecology of Lichen-Forming Fungi: Lichen Substances, Chemosyndromic Variation and Origin of Polyketide-Type Metabolites (Biosynthetic Pathways). In: Upreti D., Divakar P., Shukla V., Bajpai R. (eds) Recent Advances in Lichenology. Springer, New York, pp 161-179.

[2] Mosbach, K. (1969). Biosynthesis of lichen substances, products of a symbiotic association. Angew. Chem. Int. Ed. Engl., 8, 240-250.

[3] Varol, M., Türk, A., Candan, M., Tay, T., Koparal, A.T. (2016). Photoprotective Activity of Vulpinic and Gyrophoric Acids Toward Ultraviolet B-Induced Damage in Human Keratinocytes. Phytother. Res., 30, 9-15. 
[4] Chen, J., Blume, H-P., Beyer, L. (2000). Weathering of rocks induced by lichen colonization-a review. Catena, 39,121-146.

[5] Nguyen, K-H., Chollet-Krugler, M., Gouault, N., Tomasi, S. (2013). UV-protectant metabolites from lichens and their symbiotic partners. Nat. Prod. Rep., 30,1490-1508.

[6] Paudel, B., Datta-Bhattarai, H., Prasad-Pandey, D., Seoun-Hur, J., Gyu-Hong, S., Kim, IC., Han-Yim, J. (2012). Antioxidant, antibacterial activity and brine shrimp toxicity test of some mountainous lichens from Nepal. Biol. Res., 45, 387-391.

[7] Kumar, J., Dhar, P., Tayade, A.B., Gupta, D., Chaurasia, O.P., Upreti, D.K., Arora, R., Srivastava, R.B. (2014). Antioxidant capacities, phenolic profile and cytotoxic effects of saxicolous lichens from trans-Himalayan cold desert of Ladakh. PloS one, 9, e98696.

[8] Elix, J.A., Stocker-Wörgötter, E. (2008). Biochemistry and secondary metabolites. In: Nash IIITH (eds) Lichen Biology. 2 edn. Cambridge University Press, Cambridge, pp 104-133.

[9] Rubio, C., Fernández, E., Hidalgo, M.E., Quilhot, W. (2002). Effects of solar UV-B radiation in the accumulation of rhizocarpic acid in a lichen species from alpine zones of Chile. Boletín de la Sociedad Chilena de Química, 47, 67-72.

[10] Hidalgo, M., Fernández, E., Ponce, M., Rubio, C., Quilhot, W. (2002). Photophysical, photochemical, and thermodynamic properties of shikimic acid derivatives: calycin and rhizocarpic acid (lichens). J. Photochem. Photobiol. B, Biol., 66, 213-217.

[11] Rouvray, D.H. (1990). The evolution of the concept of molecular similarity. In: Johnson, M.A., Maggiora, G.M. (eds) Concepts and applications of molecular similarity. Wiley, New York, pp 15-42.

[12] Warr, W.A. (2011). Some Trends in Chem (o) informatics. In: Bajorath, J. (eds) Chemoinformatics and Computational Chemical Biology. Humana Press, Germany, pp 137.

[13] Peltason, L., Bajorath, J. (2011). Computational analysis of activity and selectivity cliffs. In: Bajorath, J. (eds) Chemoinformatics and Computational Chemical Biology. Humana Press, Germany, pp 119-132.

[14] Rashidi, H.H., Buehler, L.K. (2005). Bioinformatics basics: applications in biological science and medicine. CRC press, Boca Raton, Florida.

[15] Shukla, V., Joshi, G.P., Rawat, M. (2010). Lichens as a potential natural source of bioactive compounds: a review. Phytochem. Rev., 9, 303-314.

[16] Shrestha, G., Clair, L.L.S. (2013). Lichens: a promising source of antibiotic and anticancer drugs. Phytochem. Rev., 12, 229-244.

[17] Lohézic-Le Dévéhat, F., Legouin, B., Couteau, C., Boustie, J., Coiffard, L. (2013). Lichenic extracts and metabolites as UV filters. J. Photochem. Photobiol. B, Biol., 120, 17-28.

[18] Huneck, S., Yoshimura, I. (1996). Identification of lichen substances. Springer, Berlin, Heidelberg.

[19] Maalouf, S., El-Sabban, M., Darwiche, N., Gali-Muhtasib, H. (2002). Protective effect of vitamin E on ultraviolet B light-induced damage in keratinocytes. Mol. Carcinog., 34, 121 130.

[20] Goel, R.K., Singh, D., Lagunin, A., Poroikov, V. (2011). PASS-assisted exploration of new therapeutic potential of natural products. Med. Chem. Res., 20, 1509-1514.

[21] He, Y., Liew, C.Y., Sharma, N., Woo, S.K., Chau, Y.T., Yap, C.W. (2013). PaDELDDPredictor: Open-source software for PD-PK-T prediction. J. Comput. Chem., 34, 604610. 
[22] Mathew, S., Faheem, M., Archunan, G., Ilyas, M., Begum, N., Jahangir, S., Qadri, I., Al Qahtani, M., Mathew, S. (2014). In silico studies of medicinal compounds against hepatitis C capsid protein from north India. Bioinform. Biol. Insights, 8, 159-168.

[23] Varol, M., Tay, T., Candan, M., Turk, A., Koparal, A.T. (2015). Evaluation of the sunscreen lichen substances usnic acid and atranorin. Biocell, 39, 25-31.

[24] Harvey, A.L. (2008). Natural products in drug discovery. Drug Discov. Today, 13, 894901.

[25] Dimitrova, V., Kaneva, M., Gallucci, T. (2009). Customer knowledge management in the natural cosmetics industry. Industrial Management \& Data Systems, 109, 1155-1165.

[26] Chang, Y.H. (2011). Consumer and Formulator of Natural Cosmetics: Understanding and Integrating Each Other's Needs. In: Dayan, N., Kromidas, L., Formulating, Packaging, and Marketing of Natural Cosmetic Products, John Wiley \& Sons, Inc., Hoboken, New Jersey, 5-26.

[27] Koehn, F.E., Carter, G.T. (2005). The evolving role of natural products in drug discovery. Nat. Rev. Drug. Discov., 4, 206-220.

[28] Molnár, K., Farkas, E. (2010). Current results on biological activities of lichen secondary metabolites: a review. Z. Naturforsch. C, 65, 157-173.

[29] Boustie, J., Grube, M. (2005). Lichens-a promising source of bioactive secondary metabolites. Plant. Genet. Resour., 3, 273-287.

[30] Ranković, B., Kosanić, M. (2015). Lichens as a potential source of bioactive secondary metabolites. In: Ranković, B. (eds) Lichen Secondary Metabolites. Springer, pp 1-26

[31] Thevanayagam, H., Mohamed, S.M., Chu, W-L. (2014). Assessment of UVBphotoprotective and antioxidative activities of carrageenan in keratinocytes. J. Appl. Psychol., 26, 1813-1821.

[32] Kokubun, T., Shiu, W.K.P., Gibbons, S. (2007). Inhibitory activities of lichen-derived compounds against methicillin-and multidrug-resistant Staphylococcus aureus. Planta Med., 73, 176-179.

[33] Fernández-Moriano, C., Divakar, P.K., Crespo, A., Gómez-Serranillos, M.P. (2015). Neuroprotective activity and cytotoxic potential of two Parmeliaceae lichens: Identification of active compounds. Phytomedicine, 22, 847-855.

[34] Legouin, B., Lohézic-Le Dévéhat, F., Ferron, S., Rouaud, I., Le Pogam, P., Cornevin, L., Bertrand, M., Boustie, J. (2017). Specialized Metabolites of the Lichen Vulpicida pinastri Act as Photoprotective Agents. Molecules, 22, E1162. 